\title{
Antihypertensive Drug Utilization and Blood Pressure Control in a Nigerian Hypertensive Population
}

\section{Oluwabunmi Oke ${ }^{1}$ and Aduragbenro Adedapo ${ }^{2 *}$}

${ }^{1}$ Faculty of Pharmacy, University of Ibadan, Ibadan, Nigeria

${ }^{2}$ Department of Pharmacology and Therapeutics, College of Medicine, University of Ibadan, Ibadan, Nigeria

*Corresponding author: Dr. Adedapo ADA, Department of Pharmacology and Therapeutics, College of Medicine, University of Ibadan, Ibadan, Nigeria, Tel: +2348033635204; E-mail: debyee1965@yahoo.co.uk

Rec date: Dec 29, 2014 Acc date: Feb 18, 2015 Pub date: Feb 25, 2015

Copyright: ( 2015 Oke O, et al. This is an open-access article distributed under the terms of the Creative Commons Attribution License, which permits unrestricted use, distribution, and reproduction in any medium, provided the original author and source are credited.

\begin{abstract}
This research work aimed at investigating the management of hypertension from statistics documented in the hospital records. Data was sourced from patients' case notes and from these records, information obtained include blood pressure readings, drugs used, comorbidities, length of treatment; these parameters were used in evaluating the prescription pattern in the management of hypertension and the recent rate of blood pressure control in the hypertensive patients as indices of the current management of hypertension. The underlying hypothesis for the work is that a longer period of evaluation should be a better metric in the evaluation of pattern of antihypertensive drug use and overall assessment of blood pressure control. The data obtained was analyzed statistically and the result revealed that the overall level of blood pressure control for the 279 patients' records reviewed was $20.4 \%$. The study revealed that the current rate of blood pressure control was low among this population.
\end{abstract}

Keywords: Antihypertensive drug utilization; Blood pressure control; Nigerian population

\section{Abbreviations:}

ACEI: Angiotensin Converting Enzyme Inhibitors; ARB: Angiotensin Receptor Blockers; BB: Beta-Blockers; CAD: CentrallyActing Drugs ( $\alpha$-Methyldopa); CCB: Calcium Channel Blockers; D: Diuretics

\section{Introduction}

In a recent study, cardiovascular diseases especially hypertension increased by $150 \%$ compared with previous report from similar setting. Hypertension and hypertension related diseases proved to be the most frequent cause of hospital admissions and stroke was the leading cause of death, (20\%) [1]. Hypertension is one of the most important causes of premature death worldwide currently affecting one in three adults worldwide; in 2025, an estimated 1.56 billion adults will be living with hypertension [2]. Moreover, Nigeria is the country with the most populous black hypertensive patients [3].

In research works carried out independently it has been opined that in spite of the availability of a wide range of anti-hypertensive drugs, hypertension and its complications are still important causes of adult morbidity and mortality in sub-Saharan Africa [4,5]. Furthermore, from studies carried out in a Nigerian population it was put forth that more than $50 \%$ of treated hypertensive patients have a blood pressure level greater than $140 / 90 \mathrm{~mm} \mathrm{Hg}$ (uncontrolled hypertension) [6,7].

There are excellent clinical outcome trial data proving that lowering BP with several classes of drugs, including angiotensin converting enzyme inhibitors (ACEIs), angiotensin receptor blockers (ARBs), beta-blockers (BBs), calcium channel blockers (CCBs), and thiazidetype diuretics (D), will all reduce the complications of hypertension.

More than two-thirds of hypertensive individuals cannot be controlled on one drug and will require two or more antihypertensive agents selected from different drug classes [8-11]. For example, in Antihypertensive and Lipid Lowering Treatment to Prevent Heart Attack Trial (ALLHAT), 60 percent of those whose BP was controlled to $<140 / 90 \mathrm{mmHg}$ received two or more agents, and only 30 percent overall were controlled on one drug [12]. In hypertensive patients with lower BP goals or with substantially elevated BP, three or more antihypertensive drugs may be required.

\section{Materials and Methods}

This research work is a cross-sectional retrospective study of hypertensive patients conducted at Jericho Specialist Hospital, a government-owned (secondary) healthcare facility in Ibadan, Oyo State. Ibadan is located in the rain forest belt of southwest Nigeria.

The study involved case notes review and use of existing data (spanning 35 months) and is subsumed in a much larger study on drug utilization for which permission was obtained from Ministry of Health and Oyo State Hospitals Management Board. Case notes for the Medical Outpatients were provided by the Records Department of the hospital.

\section{Inclusion criteria are viz.}

- Case notes of hypertensive outpatients treated between July 2009 and May 2012

- Hypertensive outpatients, male and female, between 20 and 90 years of age 
Citation: $\quad$ Oke O, Adedapo A (2015) Antihypertensive Drug Utilization and Blood Pressure Control in a Nigerian Hypertensive Population. General

Page 2 of 5

- Case notes inclusive of, at least, two (2) blood pressure readings with or without record of drugs prescribed (as some patients are placed only on lifestyle modifications)

However, case notes of patients on observation or adjunctive treatment for suggestive or clinically undiagnosed cases of hypertension were excluded. Data on patient's demographic distributions, all blood pressure values from the first visit to the clinics (initial blood pressure, BP) to the final visit (last BP) as well as comorbid conditions were extracted from their case notes. The comorbidities considered were diabetes mellitus and occurrence of cardiovascular diseases (CVD). Use or otherwise of antiplatelet aspirin was recorded as well. Antihypertensive drugs the patients had taken and/or were still taking at the time of the study were documented and grouped into their classes.

\section{The antihypertensive drug classes encountered, and consequently reckoned with, are}

- Angiotensin converting enzyme inhibitors (ACEI)

- Angiotensin receptor blockers (ARB)

- Beta-blockers (BB)

- Calcium channel blockers (CCB)

- Centrally acting agents (notably alpha-methyldopa) (ALD)

- Diuretics (D)

Concurrent use of two or more of these was documented appropriately as 2-drug, 3-drug combinations, etc. The pattern of blood pressure control was defined as:

Systolic blood pressure (SBP) and diastolic blood pressure (DBP) controlled:

$<140 / 90 \mathrm{mmHg}$

SBP controlled: $\mathrm{SBP}<140 \mathrm{mmHg}$ and $\mathrm{DBP} \geq 90 \mathrm{mmHg}$

DBP controlled: SBP $\geq 140 \mathrm{mmHg}$ and DBP $<90 \mathrm{mmHg}$

SBP and DBP uncontrolled: $>140 / 90 \mathrm{mmHg}$

The sub-group of hypertensive diabetics was analysed separately.

Data was analysed using SPSS (Statistical Package for Social Sciences, Version 17) and was summarized in proportions and percentages as appropriate, using chi-square as test association. Level of significance was at $\mathrm{p}<0.05$.

\section{Results}

The characteristics of the study population are shown in Table 1 and age distribution pattern in Figure 1. There was a clear predominance of females $(76.7 \%)$. The result showed that the mean age was $56.25 \pm 12.07$ with $65(23.3 \%)$ males $(\mathrm{M}: \mathrm{F}=1: 3.3)$. Of the study population $4.7 \%$ were diabetic, $62.3 \%$ were taking aspirin. Among the diabetic subgroup, $66.7 \%$ were taking aspirin.

\begin{tabular}{|l|l|l|}
\hline & All patients $\mathbf{( n = 2 7 9 )}$ & Diabetics (21) \\
\hline Gender: Male $\mathrm{n}(\%)$ & $65(23.3)$ & $1(4.7)$ \\
\hline Age (years) & $56.25 \pm 12.07$ & $54.95 \pm 10.4$ \\
\hline Systolic blood pressure initial $(\mathrm{mmHg})$ & $171 \pm 26$ & $165 \pm 26$ \\
\hline Diastolic blood pressure initial $(\mathrm{mmHg})$ & $99 \pm 16$ & $97 \pm 17$ \\
\hline
\end{tabular}

\begin{tabular}{|l|l|l|}
\hline Mean systolic blood pressure $_{(\mathrm{mmHg})}$ & $153 \pm 24$ & $152 \pm 23$ \\
\hline Mean diastolic blood pressure $_{(\mathrm{mmHg})}$ & $90 \pm 14$ & $87 \pm 13$ \\
\hline Aspirin $\mathrm{n}(\%)$ & $174(62.3)$ & $14(66.7)$ \\
\hline
\end{tabular}

Table 1: Characteristics of the Hypertensive Patients treated at Jericho Specialist Hospital, Ibadan between July 2009 and May 2012.

$$
\text { Drug Utilization Pattern } \quad 2.30 \pm 0.92
$$

Level of Blood pressure control $\quad 2.88 \pm 1.24$

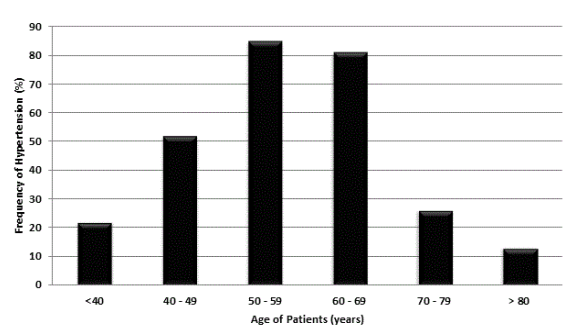

Figure 1: Age distribution of hypertensive patients treated at Jericho Specialist Hospital, Ibadan between July 2009 and May 2012.

The patterns of utilization of antihypertensive drugs are shown in Table 2 and Figure 2. Among the entire study population, diuretics were the most commonly used antihypertensive drugs, which accounted for $78.6 \%$; this was followed by centrally-acting drugs, $\alpha$ methyldopa (61.4\%), calcium channel blockers (50.5\%), angiotensin converting enzyme inhibitors (31.2\%), beta-blockers (9.5\%) while angiotensin receptor blockers accounted for a paltry $0.7 \%$ Of the patients, $86.1 \%$ were using two or more antihypertensive drugs while $10.4 \%$ were on monotherapy with the remainder on lifestyle modifications. Among diabetics, angiotensin converting enzyme inhibitors and a-methyldopa shared the highest percentage of use, accounting for $66.7 \%$; about $90 \%$ of them were using combinations of antihypertensive drugs while approximately $5 \%$ were on monotherapy.

\begin{tabular}{|l|l|l|}
\hline & All patients $(\mathrm{n}=279)$ & Diabetics (21) \\
\hline Diuretics $\mathrm{n}(\%)$ & $224(78.6)$ & $11(52.3)$ \\
\hline Calcium channel blockers $\mathrm{n}(\%)$ & $144(50.5)$ & $12(57.1)$ \\
\hline $\begin{array}{l}\text { Angiotensin converting enzyme } \\
\text { inhibitors } \mathrm{n}(\%)\end{array}$ & $89(31.2)$ & $14(66.7)$ \\
\hline Alpha-methyldopa $\mathrm{n}(\%)$ & $175(61.4)$ & $14(66.7)$ \\
\hline Beta-blockers $\mathrm{n}(\%)$ & $27(9.5)$ & $1(4.7)$ \\
\hline Angiotensin receptor blockers $\mathrm{n}(\%)$ & $2(0.7)$ & $1(4.7)$ \\
\hline Monotherapy $\mathrm{n}(\%)$ & $29(10.4)$ & $1(4.7)$ \\
\hline 2-drug $\mathrm{n}(\%)$ & $116(41.6)$ & $6(28.5)$ \\
\hline 3-drug $\mathrm{n}(\%)$ & $97(34.8)$ & $11(52.3)$ \\
\hline 4-drug $\mathrm{n}(\%)$ & $26(9.3)$ & $2(9.5)$ \\
\hline 5-drug $\mathrm{n}(\%)$ & $1(0.4)$ & 0 \\
\hline
\end{tabular}


Citation: $\quad$ Oke O, Adedapo A (2015) Antihypertensive Drug Utilization and Blood Pressure Control in a Nigerian Hypertensive Population. General

Page 3 of 5

\begin{tabular}{|l|l|l|}
\hline No drug (lifestyle modification) n (\%) & $10(3.6)$ & $1(4.7)$ \\
\hline
\end{tabular}

Table 2: Utilization pattern of antihypertensive drugs among hypertensive patients treated at Jericho Specialist Hospital, Ibadan between July 2009 and May 2012.

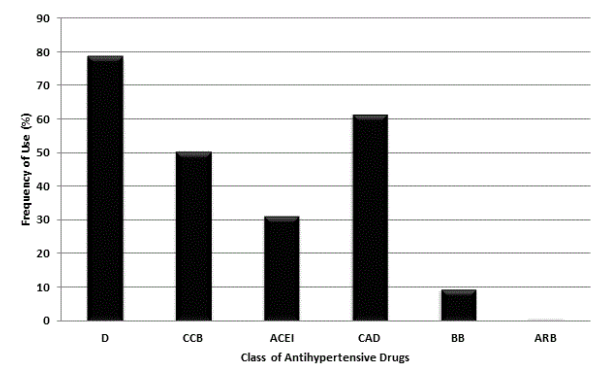

Figure 2: Drug utilization pattern among hypertensive patients treated at Jericho Specialist Hospital, Ibadan between July 2009 and May 2012. ACEI: Angiotensin Converting Enzyme Inhibitors; ARB: Angiotensin Receptor Blockers; BB: Beta-Blockers; CAD: CentrallyActing Drugs ( $\alpha$-Methyldopa); CCB: Calcium Channel Blockers; D: Diuretics.

Table 3 with Figure 3 comparatively show the effects of drug prescribed on the overall blood pressure control with the respective significance values. Overall, 20.4\% of the entire patients have their BP at the World Health Organization (WHO)-recommended target of less than $140 / 90 \mathrm{mmHg}$ while $56.3 \%$ was not controlled. The tables also revealed that SBP was more difficult to control than DBP. The control rates among the subgroup of hypertensive-diabetics are comparable with the entire study population using $<140 / 90 \mathrm{mmHg}$ as the goal. However, when the recommended target of $<130 / 80 \mathrm{mmHg}$ was applied to this subgroup, only $9.5 \%$ achieved control while $81 \%$ were uncontrolled.

\begin{tabular}{|c|c|c|c|c|c|c|}
\hline & \multicolumn{5}{|c|}{ Pattern of blood pressure control } & \multirow{2}{*}{$\begin{array}{l}P \text { - } \\
\text { value }\end{array}$} \\
\hline & $\begin{array}{l}\text { Fully } \\
\text { controlle } \\
\text { d } 57 \\
(20.4 \%)\end{array}$ & $\begin{array}{l}\text { Fully } \\
\text { uncontroll } \\
\text { ed } 143 \\
(51.3 \%)\end{array}$ & $\begin{array}{l}\text { Only } \\
\text { SBP } \\
\text { controll } \\
\text { ed } 18 \\
(6.5 \%)\end{array}$ & $\begin{array}{l}\text { Only } \\
\text { DBP } \\
\text { controlle } \\
\text { d } \quad 61 \\
(21.9 \%)\end{array}$ & \begin{tabular}{|l} 
Total \\
279 \\
$(100 \%)$
\end{tabular} & \\
\hline \multicolumn{7}{|c|}{$\begin{array}{l}\text { Gender } \\
\text { (\%) }\end{array}$} \\
\hline $\begin{array}{l}\text { Male } \\
\text { Female }\end{array}$ & $\begin{array}{l}18 \\
(6.5 \%) \\
39(14 \%)\end{array}$ & $\begin{array}{l}29(10.4 \%) \\
114 \\
(40.9 \%)\end{array}$ & \begin{tabular}{|l}
$4(1.4 \%)$ \\
14 \\
$(5.0 \%)$
\end{tabular} & \begin{tabular}{|l}
14 \\
$(5.0 \%)$ \\
47 \\
$(16.8 \%)$
\end{tabular} & \begin{tabular}{|l}
65 \\
$(23.3 \%)$ \\
214 \\
$(76.7 \%)$
\end{tabular} & NS \\
\hline \multicolumn{7}{|c|}{ Drugs N (\%) } \\
\hline Diuretics & $\begin{array}{l}44 \\
(15.8 \%)\end{array}$ & $\begin{array}{l}114 \\
(40.9 \%)\end{array}$ & \begin{tabular}{|l}
14 \\
$(5.0 \%)$
\end{tabular} & \begin{tabular}{|l}
52 \\
$(18.6 \%)$
\end{tabular} & \begin{tabular}{|l}
224 \\
$(80.3 \%)$
\end{tabular} & NS \\
\hline $\begin{array}{l}\text { Centrally } \\
\text { Acting } \\
\text { Drugs }\end{array}$ & $\begin{array}{l}33 \\
(11.8 \%)\end{array}$ & $98(35.1 \%)$ & \begin{tabular}{|l|}
11 \\
$(3.9 \%)$
\end{tabular} & \begin{tabular}{|l}
33 \\
$(11.8 \%)$
\end{tabular} & \begin{tabular}{|l}
175 \\
$(62.7 \%)$
\end{tabular} & NS \\
\hline $\begin{array}{l}\text { Calcium } \\
\text { Channel } \\
\text { Blockers }\end{array}$ & $\begin{array}{l}24 \\
(8.6 \%)\end{array}$ & $86(30.8 \%)$ & $7(2.5 \%)$ & \begin{tabular}{|l}
27 \\
$(9.7 \%)$
\end{tabular} & $\begin{array}{l}144 \\
(51.6 \%)\end{array}$ & 0.033 \\
\hline
\end{tabular}

\begin{tabular}{|c|c|c|c|c|c|c|}
\hline $\begin{array}{l}\text { Angiotensin } \\
\text { Converting } \\
\text { Enzyme } \\
\text { Inhibitors }\end{array}$ & $\begin{array}{l}13 \mathrm{~F} \\
(4.7 \%)\end{array}$ & $48(17.2 \%)$ & $5(1.8 \%)$ & $\begin{array}{l}23 \\
(8.2 \%)\end{array}$ & $\begin{array}{l}89 \\
(31.9 \%)\end{array}$ & NS \\
\hline $\begin{array}{l}\text { Beta } \\
\text { Blockers }\end{array}$ & $7(2.5 \%)$ & $13(4.7 \%)$ & $2(0.7 \%)$ & $5(1.8 \%)$ & $\begin{array}{l}27 \\
(9.7 \%)\end{array}$ & NS \\
\hline $\begin{array}{l}\text { Angiotensin } \\
\text { Receptor } \\
\text { Blockers }\end{array}$ & $0(0 \%)$ & $0(0 \%)$ & $1(0.4 \%)$ & $1(0.4 \%)$ & $2(0.7 \%)$ & 0.044 \\
\hline $\begin{array}{l}\text { Drug usage } \\
\mathbf{N}(\%)\end{array}$ & & & & & & \\
\hline 0 & $2(0.7 \%)$ & $5(1.8 \%)$ & $0(0 \%)$ & $3(1.1 \%)$ & $\begin{array}{l}10 \\
(3.6 \%)\end{array}$ & \multirow{6}{*}{ NS } \\
\hline 1 drug & $\begin{array}{l}12 \\
(4.3 \%)\end{array}$ & $7(2.5 \%)$ & $3(1.1 \%)$ & $7(2.5 \%)$ & $\begin{array}{l}29 \\
(10.4 \%)\end{array}$ & \\
\hline 2 drugs & \begin{tabular}{|l}
23 \\
$(8.2 \%)$
\end{tabular} & $57(20.4 \%)$ & $9(3.2 \%)$ & $\begin{array}{l}27 \\
(9.7 \%)\end{array}$ & $\begin{array}{l}116 \\
(41.6 \%)\end{array}$ & \\
\hline 3 drugs & $\begin{array}{l}17 \\
(6.1 \%)\end{array}$ & $58(20.8 \%)$ & $6(2.2 \%)$ & $\begin{array}{l}16 \\
(5.7 \%)\end{array}$ & $\begin{array}{l}97 \\
(34.8 \%)\end{array}$ & \\
\hline 4 drugs & $3(1.1 \%)$ & $15(5.4 \%)$ & $0(0 \%)$ & $8(2.9 \%)$ & $\begin{array}{l}26 \\
(9.3 \%)\end{array}$ & \\
\hline 5 drugs & $0(0 \%)$ & $1(0.4 \%)$ & $0(0 \%)$ & $0(0 \%)$ & $1(0.4 \%)$ & \\
\hline
\end{tabular}

Table 3: Drug Utilization and Pattern of Blood Pressure Control of hypertensive patients treated in Jericho Specialist Hospital between July 2009 and May 2012. Abbreviations: $N S=$ Not significant $(p>0.05)$.

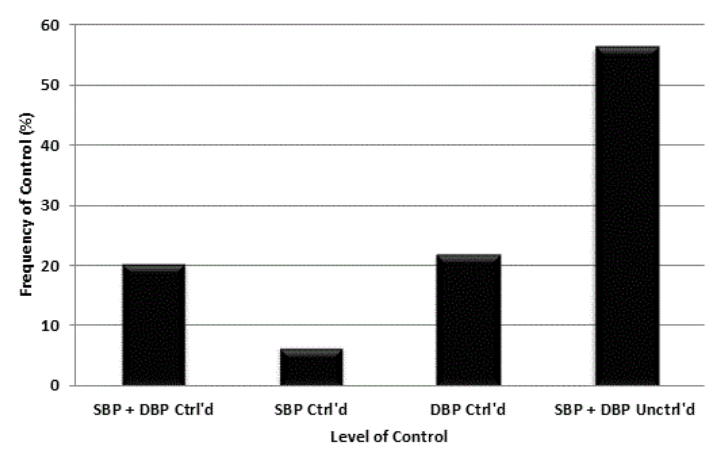

Figure 3: Overall Pattern of Blood Pressure Control. SBP: Systolic Blood Pressure, DBP: Diastolic Blood Pressure, Ctrl'd: Controlled, Unctrl'd: Uncontrolled.

\section{Discussion}

The higher proportion of females in this study is in agreement with other studies. For instance, a survey of hypertension control among 536 randomly selected hypertensive patients revealed similar proportions of female patients (M: F; $1: 63$ ) [13].

The study revealed diuretics were the most commonly prescribed antihypertensive drug group either alone or in combination. Moreover, this study recorded $86.1 \%$ use of combination therapy, $10.4 \%$ of monotherapy and $20.4 \%$ of BP control. For similar studies in Nigeria, the respective results (combination therapy, monotherapy and 
Page 4 of 5

BP control) are as follows: 73\%, 27\% and 33\% [14]; 64.4\%, 34.7\% and $25.4 \%$ [13]; a BP control as high as $70.7 \%$ was also documented whereas a study in Italy recorded a blood pressure control of $33.5 \%$ $[1,15]$. Review of other studies shows that increased usage of combination therapy is associated with higher proportions of rate of BP control. This is in consonance with the JNC 7 (Seventh Report of the Joint National Committee on Prevention, Detection, Evaluation and Treatment of High Blood Pressure) guidelines that state that small doses of different classes of antihypertensive drugs is more beneficial than a high dose of one [16].

A rather encouraging blood pressure control is mirrored in a much recent study where one hundred and sixteen (116) consecutive hypertensive subjects aged $50.9 \pm 8.6$ years were studied. Eighty-two $(70.7 \%)$ of the subjects were fully controlled on the treatment, two on lifestyle modification; while fifteen (12.9\%) of the subjects were not controlled at all. Level of blood pressure control in this study is good. Fully controlled subjects were almost twice as many than in the previous study from the same area in spite of co-payment. This suggests health education and patient counseling along with availability of free drug will help to improve adherence to antihypertensive drugs. This in turn impacts positively the blood pressure control [17].

Furthermore, the variance of the overall rate of blood pressure control in this study (20.4\%) with most previous findings may be attributed to the much higher predominance of females in this study (about 77\%). The closest in percentage of blood pressure control to that obtained in this study are $25.4 \%$ [13], and 29\% [18] [with the latter having a female percentage of 54.5\%]. From literature, females have been relatively less responsive to antihypertensive therapy in spite of meeting up with scheduled clinical visits and better adherence to treatment regimen [19]. A couple of other findings presented BP control rate of $36 \%$ and $30.5 \%$ respectively, neither of which had a female population in excess of $63 \%[6,19]$.

In this study, lifestyle modifications (such as dietary discretion and exercise, etc.) were largely unavailable in the case notes and hence were not documentable in this study just as for drug adherence being a retrospective study. Hence, a carefully planned prospective study focusing on adherence and improvement on blood pressure control would be necessary in further studies.

Although the findings of this study cannot be said to be an absolute representation of the general control pattern in Nigeria as a whole since this is just the experience of a single healthcare centre. Nonetheless, the BP control rate of $20.4 \%$ is in keeping with the aggregate figure for the sub-Saharan African region, where the overall control rate was put at $<20 \%$ in a systematic review [20].

Finally, the strength of this study lies firstly in the unparalleled period of consideration (thirty-five [35] months). Earlier studies have been characterized by a relatively short period of consideration (usually not exceeding three [3] months) [3,21,22] with a tangible majority of them having comparatively smaller sample sizes [14,21-24]. It is noteworthy also that there is no prior study of this kind in a secondary healthcare setting. Furthermore, the result of this study represents a much more recent (and arguably more reliable) assessment of the subject matter and, as such, is hoped to not only merit publication but also attract attention as a renewed, data-driven basis for further research in the management and control of hypertension, ultimately.

\section{Conclusion}

This research reveals that the rate of blood pressure control in this part of the world is still rather poor and is apparently worse off than before, implying a decline in the control of hypertension. It is advanced, therefore, that improved adherence to international guidelines for managing hypertension, regarding each strategy of therapy as integral, never as adjunctive as well as a patient-oriented approach that progressively corrects erroneous cultural stereotypes regarding drug utilization, dietary habits and weight gain will make for an improved rate of blood pressure control in the face of an everexpanding population.

\section{Acknowledgements}

We sincerely acknowledge the kind efforts of Dr. Aderounmu of Jericho Specialist Hospital, Ibadan as well as the magnanimity of Records Department staffers in the same hospital. Their combined input was instrumental to the success of this research work.

\section{References}

1. Adedapo ADA, Fawole O, Bamgboye A, Adedapo K, Demmisie K, et al. (2012) Morbidity and mortality patterns of medical admissions in a Nigerian secondary health care hospital. Afr J Med Med Sci 41: 13-20.

2. World Health Organization (WHO) Hypertension Fact Sheet (2011) Department of Sustainable Development and Healthy Environment.

3. Olanrewaju TO, Aderibigbe A, Busari OA, Sanya EO (2010) Antihypertensive drug utilization and conformity to guidelines in a subSaharan African hypertensive population. International Journal of Clinical Pharmacology and Therapeutics 48: 68-75.

4. Isezuo SA, Omotoso ABO, Gaye A, Corrah T, Araoye MA (2000) One year survival among sub-Saharan Africans with hypertensive heart failure. Tropical Cardiology 26: 57-60.

5. Cappuccio FP, Micah FB, Emmett L, Kerry SM, Antwi S, et al. (2004) Prevalence, detection, management, and control of hypertension in Ashanti, West Africa. Hypertension 43: 1017-1022.

6. Salako BL, Ajose FA, Lawani E (2003) Blood pressure control in a population where antihypertensives are given free. East Afr Med J 80: 529-531.

7. Isezuo AS, Njoku CH (2003) Blood pressure control among hypertensives managed in a specialised health care setting in Nigeria. See comment in PubMed Commons below Afr J Med Med Sci 32: 65-70.

8. Hansson L, Zanchetti A, Carruthers SG, Dahlof ZB, Elmfeldt D, et al. (1998) Effects of intensive blood-pressure lowering and low-dose aspirin in patients with hypertension: Principal results of the Hypertension Optimal Treatment (HOT) randomised trial. HOT Study Group. Lancet 351: 1755-1762.

9. Black HR, Elliott WJ, Grandits G, Grambsch P, Lucente T, et al. (2003) Principal results of the Controlled Onset Verapamil Investigation of Cardiovascular End Points (CONVINCE) trial. JAMA 289: 2073-2082.

10. Dahlöf B, Devereux RB, Kjeldsen SE, Julius S, Beevers G, et al. (2002) Cardiovascular morbidity and mortality in the Losartan Intervention For Endpoint reduction in hypertension study (LIFE): a randomised trial against atenolol. Lancet 359: 995-1003.

11. Materson BJ, Reda DJ, Cushman WC, Massie BM, Freis ED, et al. (1993) Single-drug therapy for hypertension in men. A comparison of six antihypertensive agents with placebo. The Department of Veterans Affairs Cooperative Study Group on Antihypertensive Agents. N Engl J Med 328: 914-921.

12. Cushman WC, Ford CE, Cutler JA, Margolis KL, Davis BR, et al. (2002) Success and predictors of blood pressure control in diverse North American settings: The Antihypertensive and Lipid-Lowering Treatment to Prevent Heart Attack Trial (ALLHAT). J Clin Hypertens (Greenwich) 4: 393-404. 
Citation: $\quad$ Oke O, Adedapo A (2015) Antihypertensive Drug Utilization and Blood Pressure Control in a Nigerian Hypertensive Population. General

13. Salako BL, Ayodele OE, Kadiri S, Arije A. (2002) Assessment of blood pressure control in a Black African population. Trop. Cardiol 9: 3-6.

14. Sani MU, Mijinyawa MS, Adamu B, Abdu A, Borodo MM (2008) Blood pressure control among treated hypertensives in a tertiary health institution. Niger J Med 17: 270-274

15. Giannattasio C, Cairo M, Cesana F, Alloni M, Sormani P, et al. (2012) Blood pressure control in Italian essential hypertensives treated by general practitioners. Am J Hypertens 25: 1182-1187.

16. U.S. Department of Health and Human Services. (2004) Complete Report: The Seventh Report of the Joint National Committee on Prevention, Detection, Evaluation and Treatment of High Blood Pressure. National Institutes of Health, National Heart, Lung, and Blood Institute, National High Blood Pressure Education Program: NIH Publication No. 04-5230.

17. Adedapo AD, Sikuade O, Adeleke S, Okechukwu R (2012) Drug utilization and blood pressure control in a population where antihypertensives are given free: effect of policy change. See comment in PubMed Commons below Afr J Med Med Sci 41: 349-356.

18. Etuk E, Isezuo SA, Chika A, Akuche J, Ali M (2008) Prescription pattern of anti-hypertensive drugs in a tertiary health institution in Nigeria. See comment in PubMed Commons below Ann Afr Med 7: 128-132.
19. Odili VU, Oghagbon EK, Ugwa NA, Ochei UM, Aghomo OE (2008) Adherence to International Guidelines in the Management of Hypertension in a Tertiary Hospital in Nigeria. Tropical Journal of Pharmaceutical Research 7: 945-952.

20. Addo J, Smeeth L, Leon DA (2007) Hypertension in sub-saharan Africa: a systematic review. Hypertension 50: 1012-1018.

21. Yusuff KB, Balogun $\mathrm{OB}$ (2005) Physicians' prescribing of antihypertensive combinations in a tertiary care setting in southwestern Nigeria. J Pharm Pharm Sci 8: 235-242.

22. Igbiks T, Musa B (2012) Blood Pressure Control Amongst Hypertensive Patients in a Tertiary Healthcare Facility in Northern Nigeria. Res. J. Med. Sci 6: 26-32.

23. Adigun AQ, Ishola DA, Akintomide AO, Ajayi AAL (2003) Shifting trends in pharmacologic treatment of hypertension in a Nigerian tertiary hospital: a real world evaluation of the efficacy, safety, rationality and pharmacoeconomics of old and new anti-hypertensive drugs. J Hum Hypertens 17: 277-285.

24. Amira CO, Okubadejo NU. (2006) Antihypertensive pharmacotherapy in a developing economy: pattern, acquisition costs and conformity to international guidelines in a tertiary-care setting. J Human Hypertens 20: 894-897. 